\title{
JMLE \\ JOURNAL OF MEDIA LITERACY EDUCATION
}

\section{Do media literacies approach equity and justice?}

\section{2 open access}

Peer-reviewed article

Citation: $\quad$ Mihailidis, $\quad$ P., Ramasubramanian, S., Tully, M., Foster, B., Riewestahl, E., Johnson, P., \& Angove, S. (2021). Do media literacies approach equity and justice?. Journal of Media Literacy Education, 13(2), 1-14. https://doi.org/10.23860/JMLE-202113-2-1

\section{Corresponding Author:}

Paul Mihailidis pmihailidis@gmail.com

Copyright: () 2021 Author(s). This is an open access, peer-reviewed article published by Bepress and distributed under the terms of the Creative Commons Attribution License, which permits unrestricted use, distribution, and reproduction in any medium, provided the original author and source are credited. JMLE is the official journal of NAMLE.

Received: April 1, 2021

Accepted: August 30, 2021

Published: September 10, 2021

Data Availability Statement: All relevant data are within the paper and its Supporting Information files.

Competing Interests: The Author(s) declare(s) no conflict of interest.

\section{Editorial Board}

Paul Mihailidis

Emerson College, USA

Srividya Ramasubramanian

Syracuse University, USA

Melissa Tully

University of Iowa, USA

Bobbie Foster

University of Maryland, USA

Emily Riewestahl

Syracuse University, USA
Patrick Johnson

University of Iowa, USA

Sydney Angove

Emerson College, USA

\begin{abstract}
It is often assumed that media literacy serves to protect and uphold democratic practice and that media literate citizens are the best safeguards for democracy. However, little attention is paid to defining this practice and its relationship to ongoing inequities within democratic societies. In this essay, we argue media literacy operates from three core assumptions; media literacy creates knowledgeable individuals, empowers communities, and encourages democratic participation. The first assumption draws out an individual's skills and critical thinking in media literacy practices. The second assumption focuses on the community aspect of media literacy, specifically which communities are best served by media literacy and why. Finally, the connection between media literacy and democratic practices is evaluated to understand how the democratic ideals of equity and justice are situated within the existing literature. Through an exploration of these assumptions, this essay provokes a discussion into the assumptions that media literacy scholarship and practice addresses to highlight some of the gaps in constructing impactful practice that centers on equity and social justice.
\end{abstract}

Keywords: media literacy, social justice, equity, civic engagement, democracy, critical pedagogy.

\section{Journal of Media Literacy Education}

THE OFFICIAL PUBLICATION OF THE

National Association for Media Literacy Education (NAMLE)

Online at www.jmle.org 


\section{INTRODUCTION}

The question posed in the title of this essay is meant to provoke a discussion. A discussion that we feel is central to the future of media literacy education practices in formal and informal learning spaces. The field of media literacy has made great strides in past decades. Resources for educators have grown in response to increasing calls for media literacy education to respond to the ubiquity of media in daily life and the resulting effects on information and communication norms in the United States today. The spread of misinformation is but one of the challenges that has seen growing attention in education spaces, resulting in calls for more media literacy opportunities for students. At the same time, growing inequities, social, political, environmental and economic, have called to question how media literacy practices are addressing issues of social justice and equity. In this essay, we ask how explicitly or implicitly media literacy educational practices are positioned to support positive social change for equitable and just democratic futures in the United States. Informed by a national research initiative led by the authors to understand how media literacy practices in the United States address and approach equity and social justice, below we explore contemporary media literacy research and practice to probe this question. To do so, we ground the paper in three long-standing assumptions we identify in media literacy research and practice: the prioritization of individual agency, community engagement, and democratic participation for all people.

By sharing our initial explorations of these assumptions, we hope to contribute to conversations about the relationship between media literacy and its public goals. We hope to provoke discussions around media literacy and issues of equity and inclusion in the United States. And we hope to evoke new directions for researchers and practitioners interested in the assumptions and relationships we explore. JMLE's call for papers in this special issue asks us to consider what roles media literacy can and should play in the push for racial and social justice. We hope that this essay evokes questions, complexities and ideas that can help media literacy researchers and practitioners ask more questions about how their work approaches issues of social justice and equity.

As media technologies continue to develop and change rapidly, providing young people with the knowledge and skills needed to navigate their mediated realities is of the utmost priority. The urgency of media literacy has only grown in the face of increasing misinformation, cyber warfare, partisan politics, economic inequalities, climate change, and a global pandemic. These issues play out in digital spaces that lack regulation or oversight, and that are increasingly used for public engagement in communities and democracy. The role of large digital platforms in spreading misinformation is so great, argues Joan Donovan, "that fighting it is like bringing a garden hose to a 30-story building that's on fire" (Verma, 2021). Traditionally, media literacy educational practices prioritize acquiring skills and knowledge to build critical thinking that transfers into daily life. The pace of change and sophistication of media technologies evokes the question of what knowledge and skills matter, and how effectively they transfer to the issues that challenge democratic norms. At the same time, media literacy efforts are often targeted to communities that have the resources to implement them, primarily public and private schools in higher socio-economic areas and community organizations with the resources available to provide technology and media training (boyd, 2014; Noell, 2014; Van Deursen, Helsper, \& Eynon, 2014).

There is great urgency to advance media literacy in a time of deepening social, political, and economic divides. Calls for media literacy education have been made specifically in response to increasing political polarization and hyper-weaponized disinformation (Beaufort, 2018; Frechette, 2019; Hobbs, 2010). Recent research shows that media literacy can improve knowledge and skills to navigate digital information environments and increase knowledge about news and misinformation (Amazeen \& Bucy, 2019; McGrew et al., 2018 Wineburg et al., 2016). However, digital navigation skills do not directly address the underlying historical and social climates that create disinformation and hyper-partisan media spaces. As civic infrastructures continue to fracture, media literacy must not only continue to teach skills and competencies to navigate digital media spaces but must do so to dismantle social inequalities and foreground democratic principles of equity, voice, care, and social justice.

To explore the question posed in the title of this essay, we review existing research to locate a pattern of assumptions that underlie media literacy practice in the United States: 1) media literacy education prioritizes individual agency, 2) media literacy education empowers communities, and 3) media literacy education promotes democratic well-being. We approach these assumptions from a social justice perspective by asking who benefits from these assumptions and who is left out. We acknowledge that the assumptions we are 
interrogating have and continue to lead to important work in the field. And these assumptions are regularly inclusive of issues related to diversity, equity and inclusion. We argue, however, that the future of media literacy practice and research must work to prioritize equity-orientations for the design and dissemination of learning opportunities in formal and informal spaces to address pressing social, civic and democratic issues in the United States.

\section{Assumptions of equitable media literacy practices}

It is often assumed that media literacy education protects and upholds democratic practice and that media literate citizens are the best safeguards for democracy. However, little attention is paid to defining this practice and its relationship to ongoing inequities within democratic societies. Invoking Freire's work in critical literacy, Comber (2015, p. 363) writes about the problems with the assumption that education is a means of social justice:

Education, literacy, in particular, is often purported to offer the possibility of social justice. For some 'working-class' and immigrant baby boomers, completing high school and going on to higher education was indeed the ticket out of the kinds of poverty experienced by our parents and grandparents.

Comber proceeds to unpack the complex relationship between educators and social justice, focusing explicitly on the intersection of people, places, and poverty. She concludes that without this specific context, in the Freirean mold of critical consciousness, critical literacies for social justice will continue to reify the status quo:

Designing a curriculum with a social justice agenda requires knowledge about the relationships between people, places, and poverty. This will mean enhancing teacher knowledge of economics, statistics, geography, politics, and history. Future critical literacy practices need to engage teachers and students in investigating relationships between changing phenomena, including money, rather than a static embracing of the old socalled basics and compliance with the status quo. (Comber, 2015, p. 366)

The connections between media literacies and social justice have long centered around information access, media ownership, analysis of power dynamics in media, voice, and manipulation (Kibbey, 2011; Saunders, 2017). These inquiries have been present in media literacy practices for some time. More recently, the emergence of "critical media literacy" has positioned media literacy practices to be more aligned with social justice goals. Kellner and Share (2019) advocate for critical media literacy approaches to "empower individuals and groups traditionally excluded" so that "education can be reconstructed to make it more responsive to the challenges of a democratic and multicultural society" (p. xvii-xviii). They situate social justice orientations within their approach to media literacy, where educators must re-imagine their work through a social justice lens to interrogate media's complicity in the status quo and focus on how to combat inequities through media practice.

In a theoretical treatment of critical media literacy as transformative pedagogy, Funk, Kellner, and Share (2016) incorporate social justice as a core element of their movement towards media literacies that activate "critical competencies for unveiling the social constructions of normality" (p. 326). They believe that mainstream media literacy research often delegitimizes critical media literacies as protectionist, negative, and accusatory. They promote an approach to media literacy grounded in the explicit aim to cultivate social justice orientations for emerging global citizens. Their concepts - social constructivism, language/semiotics, audience/positionality, politics of representation, production/institutions, social justice (Funk et al., 2016, p. 324) - are situated in the collective goal of transformative learning experiences for more just media and civic existences.

While calls for media literacy practices that support social justice are evident, they are, we argue, on the margins of media literacy practices. The assumptions we interrogate here are positioned to explore how they address the social, political, and economic realities that continue to create and sustain inequities in the United States. It is assumed that media literacy education fosters individual agency and increases engagement in civic participation. But to what extent? Is it enough to provide media skills to individuals without including guiding principles and values that enable them to use those skills ethically? It is assumed that media literacy education empowers communities; however, how well it serves marginalized communities and to what end is often under-studied. Is it enough to provide media skills and tools to underserved communities, or do media literacy initiatives need to focus on better serving communities that lack access and support in many other ways? It is often assumed that more media literacy will lead to a stronger democracy. Is it enough to assume that media literacy can support equity, care, voice and participation? 
A note on our position towards these assumptions, and constraints of this position

We interrogate these assumptions to provoke conversations around the question that frames this essay: Do media literacies approach equity and justice? Within this exploration, we realize that the meanings and applications of these terms may not be explicit in media literacy research, and therefore, we don't assume that social justice frames are necessarily absent if these terms are not used. Rather, we believe that social justice and equity need to be explicit in all media literacy practices, or we face the risk of promoting media literacies that reify the structures of inequity within which media and education systems operate. We also are aware that these assumptions - individual agency, community empowerment, and democratic health - are not the only ones made by media literacy educators, practitioners, and researchers. They are, however, the assumptions that we feel need interrogation if they are to guide research and practice in media literacy moving forward. In their essay, "Transforming Teaching and Learning Through Critical Media Literacy," Garcia, Seglem, and Share (2013) write: "Using critical media literacy, social justice educators can bring questions of racism, homophobia, classism, sexism, and so forth into the classroom through examining media and popular culture that students are seeing, hearing, and using every day. In addition, critical media literacy pedagogy is based on Freirean notions of praxis that link theory with action, especially as students create their own media representations for audiences beyond the classroom walls" (p. 113). We believe this disposition should not simply be within the critical media literacy domain but must guide media literacy practices to fulfill their social and civic obligations. Although we present these assumptions separately, we intend to show that they are deeply intertwined and interconnected and our approach to each has implications for the others.

The assumptions below are put forth in the context of certain constraints and realities within our public education systems. In writing this work, we acknowledge the sensitivity within which social justice and equity issues exist in schools and communities. For example, present debates on critical race theory, however much they lack accuracy, bring to bear the partisanship and polarizing beliefs about issues related to diversity, equity and inclusion. The current partisan fervor that envelopes issues of social justice and equity make the reality of these orientations challenging. Even mainstream media literacy practices, designed to be apolitical, can be seen as too political for schools to adopt. In this essay we acknowledge the often perceived "radicality" of media literacy education, and the challenges this presents to our schools. This also reinforces our position on the necessity for media literacy practices to find nuanced approaches to such topics in classrooms and beyond.

We also acknowledge in our work the perception of paternalism when writing about media literacies and marginalized communities. Our research team, and the reviewers of this paper, evoked the idea that media literacy can and will "empower disempowered communities." While we aspire to see this transformative potential for media literacy educational practices, we acknowledge the complexity of factors that contribute to the marginalization of certain communities and populations. Our assumptions below call out the inequitable distribution of media literacy educational opportunities, but we also acknowledge the amount of work that community organizations, schools and public libraries do to bring media literacy educational opportunities to their communities.

\section{Assumption 1: Media literacy education prioritizes individual agency}

The first assumption we approach is media literacy's connection to the concept of agency. Agency, public democracy scholar Harry Boyte (2020) writes, "includes a set of developing practices and concepts which enhance the capacities of diverse groups of people to work across differences to solve problems, create things of common value, and negotiate a shared democratic way of life" (p. 1). Media literacies, similarly, build the capacity for people to make smart choices about media consumption and how they choose to use media to participate in daily life. At its basic level, mainstream approaches to media literacy education assume that its pedagogies will protect people from harmful media effects, empower them to be more critical and informed media consumers, and develop more reflective and savvy media creators. Thus, longstanding approaches to media literacy incorporate frameworks that integrate skills in media analysis, deconstruction, inquiry, and production, alongside reflection, engagement, and action-taking into the world (Bulger \& Davidson, 2018). Commonly, media literacy education assumes that learners, through a process of skill attainment and critical thinking, will become more active and engaged individuals in their media ecosystems and their local, national, and global communities. 
We prioritize this assumption as it impacts media literacy at its most fundamental level in formal and informal learning environments: what do we want the outcomes of media literacy experiences to produce? In thinking about practices that center equity and justice in media literacy, we are specifically concerned with how they approach individual skill attainment and its connection to what sociologist Anthony Giddens calls "knowledgeable action." Giddens (1984) writes, "agency refers not to the intentions people have in doing things, but their capability of doing those things in the first place" (p. 9). Giddens sees agency as how humans create and recreate the social structures that support daily life. Hannah Arendt (1971) sees agency through the lens of how people feel empowered to act in public and what spaces and norms must exist for people to engage, alongside others, in the world. Media literacy, following the logic of agency, is interested in how people can critique and create media towards the goal of using their media literacy skills to be more informed, reflective, and meaningfully engaged in the world (Buckingham, 2018; Hobbs, 2017; Kellner \& Share, 2019).

Despite their attention to skills and capacities geared towards real-world application, much of the emphasis on media literacy skill attainment concentrates on personal responsibility over collective wellbeing. In their 2018 report, Monica Bulger and Patrick Davidson (2018) write, "media literacy has long focused on personal responsibility, which can not only imbue individuals with a false sense of confidence in their skills (Sanchez \& Dunning, 2018; Kruger \& Dunning, 1999) but also puts the onus of monitoring media effects on the audience, rather than media creators, social media platforms, or regulators" (p. 9). The priority placed on individual responsibility, also noted in recent research by Mihailidis (2018), can be problematic for understanding the truth in a complex digital media environment. Digital platforms design ever invasive and manipulative personal information experiences for young people, where truth becomes siloed and driven by algorithms.

Media literacy practices show that exposure to learning experiences can move the needle on engagement (Kahne \& Bowyer, 2017; Wineburg et al., 2016), but they often prioritize the skills and knowledge sets that can lead to this needle moving over changes in behavior or practice (Jeong et al., 2012). Behaviorchange studies are hard to develop, undertake, and sustain. At the same time, media literacy outcomes are often mapped along the same socio-economic divides that harm educational institutions in general and society at large. A study by Kahne, Lee, and Feezel (2012) with public school students in the state of California found that traditional media literacy practices, such as learning how to analyze information and navigate online spaces for information purposes, could lead to more political interest, exposure to diverse ideas, and discussion about politics in the home. They found, however, that such learning experiences were more available to youth in higher socio-economic areas than those with fewer resources. With the same sample, Kahne and Bowyer (2019) found that increased opportunities to learn about digital media and politics can increase youth's disposition to be politically active online, but "significant inequities" exist in terms of who participates and how. A study by Martens and Hobbs (2015) found that students from higher SES backgrounds improved media and news analysis skills through exposure to learning modules in the classroom. Ashley, Maksl, and Craft (2017) find in a survey of youth at East Coast universities concerning their news media literacy skills that increased education about media can nudge young people to increased political engagement, but this again aligns with the inequities in educational systems in the United States.

In their review of research, Bulger and Davidson (2018) suggest that "as a field, media literacy suffers from issues plaguing education generally; primarily, the longitudinal nature of media literacy creates difficulty in evaluating the success of particular training initiatives. Across education, a diversity of goals leads to incoherent expectations of outcomes, making decisions about what is measured, how, and why very important" (p. 11). Beyond media literacy education resources graphing onto existing socio-economic barriers, there is the concern that technical skill sets are not inherently ethical or do not center social justice. While it is true media literacy education can bolster political engagement, we must question in what ways this engagement is happening. The rise of politically active Internet subcultures, such as Qanon, the Red Pill Right, and Incels, demonstrates the need for media literacy practitioners to address how technological and critical skill sets engender the growth of socially conscious individuals. These movements directly tap into identity politics that play a role in individuals' daily lives. Moreover, there are increasing political barriers in education, such as the growing movement to remove Critical Race Theory from public schools and institutions. By prioritizing individual agency without acknowledging the identity of the person and how that 
identity maps onto larger socio-economic and political realities, media literacy education attempts to connect individual knowledge and skills to larger concepts such as community and democracy without fully grappling with how the same media literacy education can be used to create and perpetuate inequities.

\section{Assumption 2: Media literacy education empowers communities}

The second assumption we interrogate is that media literacy education can empower communities by applying principles of equity and justice at the community level. Media literacy education serve communities by making information accessible, reducing the participation gap, and shaping responsible citizenry. The word "community" means different things to different people, and in different contexts (Dempsey et al., 2011). For our purposes, we see community as connecting individual practices of media literacy with societal impacts, often sharing a sense of place with communal resources, goals, outcomes, and social norms. Communities may be distinguished based on shared interests, such as the K-Pop fan community or geocaching enthusiasts, or shared space such as a specific neighborhood or school (Theodori, 2020). Yet, various community members can have differing levels of access, resources, power, and privilege. Often taken for granted, communities' dominant values and belief systems shape media literacy practices, just as media literacy practices shape communities, especially in terms of equity and social justice (Ramasubramanian \& Darzabi, 2020).

Centering principles of equity and social justice, we examine how individualism competes with values of community practice and equitable access. In emphasizing individual knowledge and skill development, media literacy outcomes generally have centered more on individual agency than on developing active citizenship, civic engagement, and social justice (Hobbs, 2010). Media literacy education can help in community building, resilience, and collective action for bringing about social transformation (Mihailidis, 2018; Ramasubramanian \& Darzabi, 2020 Robertson \& Scheidler-Benns, 2016). However, many factors such as income, race, gender, education, and so on contribute to the gaps in media access and literacies.

The COVID-19 pandemic has made it amply clear that poorer families and communities have had limited access to broadband and wireless technologies, which are essential to today's media context (Berners-Lee,
2020). Public systems are the main spaces for many racial/ethnic minority youth or youths from working class families to access technologies. Additionally, the disproportionately high rates of juvenile delinquency and incarceration among youth of color also become another way in which access to many basic amenities in a community, including media access, is restricted (Vickery, 2016). Additionally, neoliberal market-based logic has led to the corporatization of the media industry and to large platforms dominating much of the media landscape (Taplin, 2017). Instead of serving communities and the public interest, media industries, including news media and social media spaces, have prioritized profits and individual rights rather than civic engagement and social justice (Fuchs \& Mosco, 2017).

When members of marginalized groups have media access, they often use it to "talk back" to their communities through social media spaces such as TikTok, Instagram, and Snapchat to raise social consciousness about social issues (Jackson \& Foucault Welles, 2020; Jeffries, 2011; Jenkins et al. 2018; McArthur, 2016; Ramasubramanian, 2016; Ramasubramanian, Winfield, \& Riewestahl, 2020; Villa-Nicholas, 2019; Yosso, 2002). For instance, McArthur (2016) discusses how the collaborative Black Girls Literacies Collective (BGLC) program with fifthgrade Black girls provided digital literacy education that the girls then used to create podcasts and spoken word performances, analyze hegemonic advertisements to push back against dominant mainstream representations, advocate for themselves, and become socially productive citizens while re-envisioning a transformative world for themselves as a community. The Message media literacy movement in Boston and Toronto uses media literacy and hip hop to provide space for youth of color to express their ideas, and learn to advocate for community needs (The Message Movement, n.d.).

Media literacy can empower youth to challenge and change stereotypical media representations of their community. For example, Yosso (2002) engaged youth in a media literacy project focused on critically analyzing images of Chicanas/os in film. The Chicana/o college students that participated in this project recognized the deficit-based framing of Chicanas/os in the media and were motivated to challenge these stereotypes through their behaviors, lifestyles, and professional and educational goals. Johnston-Goodstar and Sethi (2013) created a participatory critical media literacy program for Native American youth living in urban communities. Throughout this program, Native 
American youth critiqued the Whiteness of educational institutions, created media that celebrated their cultural identity, and produced counter-narratives that characterized Native American youth as superheroes rather than "risks." Alternative and community-based media challenges colonial systems by pointing out the flaws and gaps in mainstream media representations and providing counter-narratives that extend beyond the individual to the community.

Youth activists use social networks to raise awareness about issues affecting their communities, coordinate action, and highlight inequities. For example, undocumented immigrants used social media platforms in coordination with street protests to share their experiences and garner support for the DREAM Act (Jenkins et al., 2018). In 2009 and 2010, youth activists used new media such as blogs, videos, social media posts, and tweets to coordinate large-scale protests such as sit-ins at Congressional offices and the "Trail of Dreams," a 1500 mile walk from Miami to Washington, D.C. (Zimmerman \& Shresthova, 2012). In 2014, youth across the country used social media to highlight the injustice of the decision not to indict the officers that shot and killed Michael Brown and Eric Garner. Students held school walkouts and coordinated online to raise awareness of police brutality against Black men and show their solidarity with protesters (Clark, 2016). Other students created, retweeted, and shared messages that called attention to the unequal treatment and negative news framing of Black protestors. Media literacy education can empower youth to voice their concerns and actively engage others in digital and onthe-ground movements to resist and dismantle xenophobic and racist systems that impact their communities (Ramasubramanian \& Darzabi, 2020; Ramasubramanian \& Riewestahl, 2020).

Trauma-informed approaches to media and communication as healing, and social media counterspaces can transform literacies, identities, and communities (Ramasubramanian et al., in press). Beyond multicultural education, taking an explicitly anti-oppression and civic media orientation to create, analyze, and share culturally informed content can be a powerful experience for young learners (Mihailidis, 2018; Ramasubramanian \& Darzabi, 2020). Greater support for equitable media literacy practice, low-tech and low-budget media productions, and alternative spaces for counter-storytelling such as small media startups and lesser-known community media could be especially beneficial (Tracy, 2020). Media literacy organizations can also provide mentoring networks, professional development and training, and microfinancing options for small media outlets and educators to facilitate community-oriented participatory media practices.

The challenge here, of course, is that media literacy initiatives can take on a patronizing view of marginalized communities. Rather than assess the continued needs of the community, practitioners often set limited boundaries for projects and initiatives, control the means of media production, and leave once the project is concluded or funding runs out. Mainstream media literacy practices need to critically evaluate which communities truly benefit from their initiatives. Instead, the assumption is that communities will be empowered to participate in civic life by developing individual competencies, thus strengthening democracy. And while social media movements have done much to change public discourse on issues of institutional oppression, there is still a gap in media literacy research connecting community empowerment to democratic practice.

\section{Assumption 3: Media literacy education supports democracy}

The third and final assumption explores media literacy's relationship to democracy. It is important to reiterate that this essay is focused on the U.S. context and American democracy with its many contradictions and shortcomings. Despite the challenges of upholding the ideals of American democracy (Wood, 2020), approaches to media literacy are often developed with a specific type of Western democracy in mind in which informed citizens make decisions (like voting) and participate in politics in ways that serve them and their community's interests. In his book, News Literacy and Democracy, Seth Ashley (2019) asks, "Why does this [news literacy] matter, and why should we care?" And responds with a resounding, "In a word, democracy!" He goes on to say:

\footnotetext{
As individuals, we might not write laws or punish wrongdoers directly, but we do have the privilege of exercising our collective voice about who will lead us and how we will organize our societies. Many of us are able to do this at the voting booth every so often, but we also can speak freely to our representatives and our fellow citizens, and we can influence the policymaking process through a number of ways. To do any of this well, we need access to reliable information. As the challenges presented by the digital environment grow (and it will almost certainly get worse before it gets better), we need to develop our news literacy to become effective participants in democratic life. (p. 10)
} 
Ashley concludes his book by addressing larger questions of democratic life and the future of our societies, prompting us to continue to pursue democratic ideals to create a just society, as do other scholars who see democracy as fundamental to media literacy.

Although democratic principles are often embedded in media literacy practices, educators, practitioners, and researchers have often approached both democracy and media literacy with ideals in mind that we wish to bring to fruition and that we believe possible through this work without seriously considering the deficits in these approaches, particularly how they are rooted in White Eurocentric versions of democracy (Ramasubramanian $\&$ Darzabi, 2020). This version of democracy not only prioritizes individual agency and outcomes but centers Whiteness, which is often true of media literacy education as well. As Ramasubramanian and Darzabi (2020, p. 279) point out, "Simply encouraging the creation of online communities and participation is not sufficient. Collaboration and community-building should be tied clearly with a critical emancipatory approach that incorporates social justice and antioppression pedagogy."

Certain subfields of media literacy (e.g., news, information, and digital literacies) often foreground democracy and democratic ideals in their definitions, practices, and outcomes but rarely address issues of equity and social justice head-on. Rather, these notions are embedded in broader understandings of democracy and democratic practice. The News Literacy Project, for example, has as its mission, providing programs and resources to enable the public to become "active consumers of news and information and equal and engaged participants in a democracy" (About Our Organization, n.d.). The Center for News Literacy at Stony Brook University describes news literacy as essential for civil society and for a democratic society (What is news literacy?, n.d.). News literacy research has also prioritized the relationship between news literacy and democracy, often highlighting the connection between news literacy and democratic attitudes and behaviors (Fleming, 2015). Ashley, Maksl, and Craft (2017), for example, find a link between news literacy and two relevant democratic outcomes: current events knowledge and feelings of political efficacy. In their work on news literacy, Tully and Vraga (2018a, 2018b) argue that understanding the relationship between news and democracy is fundamental to developing news literacy and that news literacy efforts can promote democratic outcomes. Much of this research has focused on the relationship between news literacy and traditional political outcomes. Although this work has contributed to our understanding of these relationships, it has not challenged how we define or understand "democracy," "politics," or "participation," keeping individual-level outcomes at the forefront and not fully addressing community and societal-level change or the lack of equity and justice that plagues American democracy.

Although we know that in practice, democracy takes many forms and is highly imperfect in the United States and around the world, media literacy education has remained committed to supporting democratic ideals. What do media literacy educators, researchers, and practitioners see in this form of "democracy" that resonates so much with their own values and work? For one, both American democracy and media literacy education are built around individual agency and notions of informed decision-making. Media literacy research and practice that connects to democratic practices is, at its core, still about the individual and rooted in White Eurocentric democracy (Higdon, 2020). Although we see a shift in thinking about the harm that political participation and speech in all forms (including creative media) can cause, we tend to overlook the damage to marginalized communities that occurs from "dark participation" and when racist and sexist speech is presented as just one of many ideas to be debated in the "marketplace of ideas" (Quandt, 2018).

The high regard for the individual, free speech, and privileged versions of democracy has, at times, limited the scope of our work, but educators, researchers, and practitioners continue to develop new and innovative ways of expanding and pushing the boundaries of this work. For example, "Our Space: Being a Responsible Citizen of the Digital World" is designed to address some of these shortcomings with its focus on "ethical thinking" and participation. "Our Space," a collaboration of the GoodPlay Project and Project New Media Literacies, asks young people to "consider the impact of one's actions beyond the self and on a larger collective" (Gardner et al., 2011, p. 2). Mihailidis (2018) has argued that media literacy must be "intentionally civic" and pushes the field to move beyond traditional understandings of democratic participation and outcomes with an eye toward societal outcomes and the greater public good.

Despite the positives emerging from prioritizing the relationship between media literacy and democracy, we continue to live in a society that fails to serve all its citizens, and media and media literacy have a role to play here. We can ask, how has this obsession with 
Western democracy limited the kinds of conversations and research that we have engaged in? And who has been marginalized and left out because of the focus on media literacy and democracy? If media literacy is designed to promote individual agency and to serve communities, how (if at all) has this translated to promoting and sustaining a democracy that serves all citizens? How can media literacy education's focus move from the individual level to societal level with a mission that centers on equity and justice, and what would that look like in research and practice? As we move forward, we must expand not only our approach to media literacy education and research but also the relationship to democratic ideals and practices that extend beyond traditional means and measures.

\section{Concluding thoughts \& questions moving forward}

The assumptions advanced in this essay are intended to provoke a discussion about how media literacy research and practice approach issues of social justice and equity. Our intentions here are to complicate longheld assumptions in media literacy writing and practice that are often well-intentioned but do not prioritize social justice and equity in media literacy practice. On the individual level, we see a focus on knowledge and skill attainment with little regard for how that intersects with contemporary political, social, economic, and civic structures. On the community level, while we notice many initiatives supporting marginalized communities and populations, they are often not well resourced, not part of common media literacy narratives, or are topdown in nature with limited input from communities on the ground. On the democratic level, media literacy often promotes democratic participation but assumes Western Eurocentric approaches and largely ignores the structural inequities perpetuated by U.S. democracy itself.

We acknowledge that many media literacy initiatives do incorporate issues of social justice and equity into their practice. And many more do this important work but don't refer to it as "media literacy" per se. Nevertheless, there is a need to prioritize, with clarity, intentionality, and rigor, equitable media literacy practices that guide media literacy interventions from ideation to implementation and reflection. We believe that media literacy education to date, while making great strides in its ability to reach people of all ages, risks contributing to the social, educational, and civic inequities that exist in the United States. The moreresourced spaces of learning will have more opportunities to offer media literacies to their populations. Without frames of social justice and equity, media literacy education may be helping provide skills in media analysis and deconstruction without focusing on the inequities that are fracturing our media, civic, social, and political systems.

Even further, media literacy skills have been used by extremist groups and those driven by white-identity politics to harm marginalized communities and to spread mediated messages of hate and white supremacy. Mediated falsehoods are spread intentionally by bad actors and conspiracy theorists who falsely promote "critical thinking" and "doing your own research" in service of spreading false and harmful ideas and by audiences who believe misinformation that is often crafted to look and feel like news and high-quality content. Media literacy educators and advocates need to interrogate how groups such as Qanon utilize the same set of technical skills to organize events such as the January 6 attacks on the Capital. While we often highlight the great examples of individual agency and community activism, we cannot ignore how hate groups use the same set of skills to create distrust, disrupt communities, and organize protests and counter-protests of their own. Approaches to media literacy that are embedded in frameworks of equity and justice could counter these abuses and misuses of media literacy to empower audiences to create, consume and produce content that contributes to a more just and equitable society.

This essay, part of a larger national research initiative in which we explore how media literacy practice approaches equity and social justice as components of its work, is an entryway for us to build on the ongoing work in this area, but also to ask new questions and prompt new conversations about how media literacy practitioners and researchers can act, with intention and energy, to pursue the assumptions laid out above within the values that support equity and inclusion in our communities, and democracy. The stakeholders we have spoken with and the research we have reviewed show that, at best, markers for social justice and equity in media literacy are anecdotal and marginal to the core aims of many practitioners around the country. While research and practice in critical media literacy has made strong strides to connect media literacies to issues of social justice and equity, we believe that all practitioners must address these assumptions in their work if we are to move media literacy practices to support more equitable and just civic futures. 


\section{REFERENCES}

Amazeen, M. A., \& Bucy, E. P. (2019). Conferring resistance to digital disinformation: The inoculating influence of procedural news knowledge. Journal of Broadcasting \& Electronic Media, 63(3), 415-432. https://doi.org/10.1080/08838151.2019.1653101

Arendt, H. (1971) Thinking and Moral Considerations: A Lecture. Social Research. 417-446.

Ashley, S. (2019). News literacy and democracy. Routledge.

Ashley, S., Maksl, A., \& Craft, S. (2013). Developing a news media literacy scale. Journalism \& Mass Communication Educator, 68(1), 7-21. https://doi.org/10.1177/1077695812469802

Ashley, S., Maksl, A., \& Craft, S. (2017). News media literacy and political engagement: What's the connection? Journal of Media Literacy Education, 9(1), 79-98. https://doi.org/10.23860/JMLE-2017-9$1-6$

ASNE. (2016). ASNE Releases 2016 Diversity Survey Results. ASNE.

https://members.newsleaders.org/blog_home.asp?D isplay $=2153$

Bandura, A. (1997) Self-Efficacy: The Exercise of Control. Palgrave Macmillan.

Bandura, A. (2006) Toward a Psychology of Human Agency. Perspectives on Psychological Science, 1(2), 164-165. https://doi.org/10.1037/e416902005796

Banerjee, S. C. \& Greene, K. (2007). Anti-smoking initiatives: Effects of analysis versus production media literacy interventions on smoking-related attitude, norm, behavioral intention. Health Communication, 22(1), 37-48. https://doi.org/10.1080/10410230701310281

Berners-Lee, T. (2020, June 4). Covid-19 makes it clearer than ever: access to the internet should be a universal right. The Guardian.

https://www.theguardian.com/commentisfree/2020/ jun/04/covid-19-internet-universal-right-lockdownonline

Bonnet, J. \& Rosenbaum, J. (2019). "Fake news," misinformation, and political bias: Teaching news literacy in the $21 \mathrm{st}$ century. Communication Teacher, 34(2), 103-108. https://doi.org/10.1080/17404622.2019.1625938

boyd, d. (2014). It's Complicated. Yale University Press.
Boyte, Harry C. (2020) Deliberative democracy, public work, and civic agency. Journal of Deliberative Democracy, 10(1). https://doi.org/10.16997/jdd.190

Branscombe, M. (2020). The Network Impact of the Global COVID-19 Pandemic. The New Stack. https://thenewstack.io/the-network-impact-of-theglobal-covid-19-pandemic

Buckingham, D. (2019). The media education manifesto. Polity Press.

Bulger, M., \& Davison, P. (2018). The promises, challenges, and futures of media literacy. Journal of Media Literacy Education, 10(1), 1-21. https://doi.org/10.1002/trtr.1858

Burnett, C., \& Merchant, G. (2019). Revisiting critical literacy in the digital age. The Reading Teacher, 73(3), 263-266. https://doi.org/10.1002/trtr.1858

Chetty, K., Qigui, L., Gcora, N., Josie, J., Wenwei, L., \& Fang, C. (2018). Bridging the digital divide: measuring digital literacy. Economics: The OpenAccess, Open-Assessment E-Journal, 12(2018-23), 1-20. https://doi.org/10.5018/economicsejournal.ja.2018-23

Christian, A. J. (2019). Expanding production value: The culture and scale of television and new media. Critical Studies in Television: The International Journal of Television Studies, 14(2), 255-267. https://doi.org/10.1177/1749602019838882

Clark, L. S. (2016). Participants on the margins: \#BlackLivesMatter and the role that shared artifacts of engagement played among minoritized political newcomers on Snapchat, Facebook, and Twitter. International Journal of Communication 10(2016), 235-253.

https://ijoc.org/index.php/ijoc/article/view/3843/15 36

Collins, P. \& Bilge, S. (2020). Intersectionality. Polity Press.

Comber, B. (2015). Critical literacy and social justice. Journal of Adolescent \& Adult Literacy, 58(5), 362367. https://doi.org/10.1002/jaal.370

Couldry, N., \& Hepp, A. (2013a). Conceptualizing Mediatization: Contexts, Traditions, Arguments. Communication Theory, 23(3), 191-202. https://doi.org/10.1111/comt.12019

Craft, S., Ashley, S., \& Maksl, A. Elements of news literacy: A focus group study of how teenagers define news and why they consume it. Electronic News, 10(3), 143-160. https://doi.org/10.1177/1931243116656716 
Culver, S. H. \& Redmond, T. (2019). Media literacy snapshot. National Association for Media Literacy Education. https://namle.net/wpcontent/uploads/2019/06/SOML_FINAL.pdf

Dalton, E. M. (2017). Beyond universal design for learning: Guiding principles to reduce barriers to digital \& media literacy competence. Journal of Media Literacy Education, 9(2), 17-29. https://doi.org/10.23860/JMLE-2019-09-02-02

Dempsey, S., Dutta, M., Frey, L. R., Goodall, H. L., Madison, D. S., Mercieca, J., Nakayama, T., \& Miller, K. (2011). What is the role of the communication discipline in social justice, community engagement, and public scholarship? A visit to the CM café. Communication Monographs, 78(2), 256-271.

https://doi.org/10.1080/03637751.2011.565062

Federal Commission (2015) Broadband Progress Report. Federal Communications Commission. https://www.fcc.gov/reports-

research/reports/broadband-progress-reports/2015broadband-progress-report

Fleming, J. (2015). What do facts have to do with it? Exploring instructional emphasis in the Stony Brook news literacy curriculum. Journal of Media Literacy Education, 7(3), 73-92.

https://digitalcommons.uri.edu/jmle/vol7/iss3/6

Frechette, J. (2019). Keeping media literacy critical during the post-truth crisis over fake news. The International Journal of Critical Media Literacy, 1(1), 51-65. https://doi.org/10.1163/2590011000101004

Fuchs, C., \& Mosco, V. (2017). Marx and the political economy of the media. Haymarket Books.

Fujioka, Y. (1999). Television Portrayals and AfricanAmerican Stereotypes: Examination of Television Effects when Direct Contact is Lacking. Journalism \& Mass Communication Quarterly, 76(1), 52-75. https://doi.org/10.1177/107769909907600105

Funk, S., Kellner, D., and Share, J. (2016). Critical media literacy as transformative pedagogy. In M.N. Yildiz and J. Keengwe (Eds.) Handbook of Research on Media Literacy in the Digital Age (pp. 1-30). IGI Global. https://doi.org/10.4018/978-1-4666-96679.ch001

Gainer, J. (2012). Critical thinking: Foundational for digital literacies and democracy. Journal of Adolescent and Adult Literacy, 56(1), 14-17. https://doi.org/10.1002/jaal.96

Garcia, A., Seglem, R., and Share, J. (2013). Transforming teaching and learning through critical media literacy pedagogy. Learning Landscapes, 6(2), 109-124.

https://doi.org/10.36510/learnland.v6i2.608

Gardner, H., Davis, K., Flores, A., Francis, J.M., Graeff, E., Gilbert, S., James, C., Kaplan, E. Rundle, M., \& Ryan, J. (2011). Our Space: Being a responsible citizen of the digital world. https://clalliance.org/wpcontent/uploads/files/Our_Space_full_casebook_co mpressed.pdf

Giddens, A. (1984) The constitution of society: Outline of the theory of structuration. University of California Press.

Higdon, N. (2020). What is fake news? A foundational question for developing effective critical news literacy education. Democratic Communiqué, 29(1), 1-18.

https://journals.flvc.org/demcom/article/view/12128 3

Hobbs, R. (2010). Digital and Media Literacy: A Plan of Action. A White Paper on the Digital and Media Literacy Recommendations of the Knight Commission on the Information Needs of Communities in a Democracy. Aspen Institute. https://eric.ed.gov/?id=ED523244

Hobbs, R. (2017) Create to learn: Introduction to digital literacy. John Wiley \& Sons.

Hollywood Diversity Report (2020, October 22). Social Sciences. https://socialsciences.ucla.edu/hollywooddiversity-report-2020/

Jackson, S. J., Bailey, M., \& Welles, B. F. (2020). \#HashtagActivism: Networks of race and gender justice. MIT Press.

Jeffries, M. P. (2011). Thug life: Race, gender, and the meaning of hip-hop. University of Chicago Press.

Jenkins, H., Purushotma, R., Clinton, K., Weigel, M., and Robison, A. J. (2009). Confronting the challenges of participatory culture: Media education for the 21st century. [Occasional Paper on Digital Media and Learning.] John D. and Catherine T. MacArthur Foundation.

Jenkins, H., Shresthova, S., Gamber-Thompson, L., Kligler-Vilenchik, N., \& Zimmerman, A. (2018). By any media necessary: The new youth activism (Vol. 3). NYU Press.

Jenkins, H., Ford, S., \& Green, J. (2018). Spreadable media: Creating value and meaning in a networked culture. New York University Press.

Jeong, S. H., Cho, H., \& Hwang, Y. (2012). Media literacy interventions: A meta-analytic review. 
Journal of Communication, 62(3), 454-472. https://doi.org/10.1111/j.1460-2466.2012.01643.x

Johnston-Goodstar, K., \& Sethi, J. (2013). Reports from the Field: Native Youth Media as Social Justice Youth Development. Journal of American Indian Education, 52(3), 65-80.

http://www.jstor.org/stable/43608707

Kahne, J., \& Bowyer, B. (2017). Educating for democracy in a partisan age: Confronting the challenges of motivated reasoning and misinformation. American Educational Research Journal, 54(1), 3-34. https://doi.org/10.3102/0002831216679817

Kahne, J., \& Bowyer, B. (2019). Can media literacy education increase digital engagement in politics? Learning, Media and Technology, 44(2), 211-224. https://doi.org/10.1080/17439884.2019.1601108

Kahne, J., Nam-Jin L., \& Feezell, J. T. (2012). Digital media literacy education and online civic and political participation. International Journal of Communication, 6(24).

https://ijoc.org/index.php/ijoc/article/view/999

Kellner, D., \& Share, J. (2019). The critical media literacy guide: Engaging media and transforming education. Brill.

Kemp S. (2020, April 24). Report: Most important data on digital audiences during coronavirus. Growth Quarters - The Next Web.

https://thenextweb.com/growth-

quarters/2020/04/24/report-most-important-data-ondigital-audiences-during-coronavirus

Kibbey, J. S. (2011). Chapter four: Media literacy and social justice in a visual world. Counterpoints, 403, 50-61. https://doi.org/10.3726/b11264

Kruger, J., \& Dunning, D. (1999). Unskilled and unaware of it: how difficulties in recognizing one's own incompetence lead to inflated self-assessments. Journal of personality and social psychology, 77(6), 11-21. https://doi.org/10.1037/0022-3514.77.6.1121

La Pastina, A., Straubhaar, J., \& Sifuentes, L. (2014). Why do I feel I don't belong to the Brazil on TV? Popular Communication, 12(2), 104-116. https://doi.org/10.1080/15405702.2014.893582

LaPierre, S. S., \& Kitzie, V. (2019). "Lots of questions about "fake news"': How public libraries have addressed media literacy, 2016-2018. Public Library Quarterly, 38(4), 428-452. https://doi.org/10.1080/01616846.2019.1600391
Livingstone, S., \& Haddon, L. (Eds.). (2012). Children, risk and safety on the internet: Research and policy challenges in comparative perspective. Policy Press.

Martens, H., \& Hobbs, R. (2015). How media literacy supports civic engagement in a digital age. Atlantic Journal of Communication, 23(2), 120-137. https://doi.org/10.1080/15456870.2014.961636

Mason, L. E., Krutka, D., \& Stoddard, J. (2018). Media Literacy, Democracy, and the Challenge of Fake News. Journal of Media Literacy Education, 10(2), 1-10. https://doi.org/10.23860/JMLE-2018-10-2-1

Mastro, D. E., \& Behm-Morawitz, E. (2005). Latino Representation on Primetime Television. Journalism \& Mass Communication Quarterly, 82(1), 110-130. https://doi.org/10.1177/107769900508200108

McArthur, S. (2016). Black girls and critical media literacy for social activism. English Education, 48(4), 362-379.

https://www.jstor.org/stable/26492574

McGrew, S., Breakstone, J, Ortega, T., Smith, M, and Wineburg, S. (2018). Can students evaluate online sources? Learning from assessments of civic online reasoning. Theory \& Research in Social Education, 46(2): 165-193.

https://doi.org/10.1080/00933104.2017.1416320

Mihailidis, P. (2018). Civic media literacies. Routledge.

Mihailidis, P. (2018). Civic media literacies: reImagining engagement for civic intentionality. Learning, Media and Technology, 43(2), 152-164. https://www.tandfonline.com/doi/abs/10.1080/1743 9884.2018.1428623

Mihailidis, P., Shumow, M., and Harris, C., (2020) Civic Standpoint and the Pursuit of Media Literacies, Media Literacy in a Disruptive Media Environment. 229-241. https://doi.org/10.4324/978036781476219

Mihailidis, P., \& Thevenin, B. (2013). Media Literacy as a Core Competency for Engaged Citizenship in Participatory Democracy. American Behavioral Scientist, 57(11), 1611-1622. https://doi.org/10.1177/0002764213489015

News Literacy Project. (n.d.). About. https://newslit.org/about

Nowell, S. D. (2014) Using disruptive technologies to make digital connections: stories of media use and digital literacy in secondary classrooms. Educational Media International, 51(2), 109-123. https://doi.org/10.1080/09523987.2014.924661

Our Space: Being a Responsible Citizen of the Digital World. (2021). New medialiteracies.org. 
http://www.newmedialiteracies.org/our-spacebeing-a-responsible-citizen-of-the-digital-world

Pew Research Center. (2019). Internet/Broadband Fact Sheet. Pew Research Center: Internet, Science \& Tech. https://www.pewresearch.org/internet/factsheet/internet-broadband/

Quandt, T. (2018). Dark participation. Media and Communication, 6(4), 36-48.

Ramasubramanian, S. (2016). Racial/ethnic identity, community-oriented media initiatives, and transmedia storytelling. The Information Society, 32(5), 333-342.

https://doi.org/10.1080/01972243.2016.1212618

Ramasubramanian, S. \& Darzabi, R. (2020). Civic engagement, social justice, and media literacy. In B. Christ and B. De Abreu (Eds.). Media literacy in a disruptive media environment (pp. 272-282). Routledge.

Ramasubramanian, S. \& Riewestahl, E. Traumainformed approaches (in press). The International Encyclopedia of Health Communication.

Ramasubramanian, S., Winfield, A., \& Riewestahl, E. (2020). Positive stereotypes and counterstereotypes: Examining their effects on prejudice reduction and favorable intergroup relations. In A. Billings and S. Parrott (Eds.). Media stereotypes: From ageism to xenophobia (pp. 257-276). Peter Lang Publishers.

Robertson, L., \& Scheidler-Benns, J. (2016). Critical media literacy as a transformative pedagogy. Literacy Information and Computer Education Journal, 7(1), 2247-2253. https://doi.org/10.20533/licej.2040.2589.2016.0297

Sanchez, C., \& Dunning, D. (2018). Overconfidence among beginners: Is a little learning a dangerous thing?. Journal of Personality and Social Psychology, 114(1), 10. https://doi.org/10.1037/pspa0000102

Saunders, L. (2017). Connecting information literacy and social justice: Why and how.Communications in Information Literacy 11(1), 15. https://doi.org/10.15760/comminfolit.2017.11.1.47

Stony Brook University. What is news literacy? https://www.centerfornewsliteracy.org/what-isnews-literacy

Taplin, J. (2017). Move fast and break things: How Facebook, Google, and Amazon cornered culture and undermined democracy. Little, Brown, and Company.
The Center for News Literacy at Stony Brook University. (n.d.). What is news literacy? https://www.centerfornewsliteracy.org/what-isnews-literacy

The Message Movement. (n.d.). https://www.themessagemovement.com

Theodori, G. (2020). Community and Community Development in Resource-Based Areas: Operational Definitions Rooted in an Interactional Perspective. Society and Natural Resources, 18(7), 661-669. https://doi.org/10.1080/08941920590959640

Tracy, M. (2020, April 13). News media outlets have been ravaged by the pandemic. New York Times. https://www.nytimes.com/2020/04/10/business/med $\mathrm{ia} /$ news-media-coronavirus-jobs.html

Tully, M., \& Vraga, E. K. (2018a). Who experiences growth in news media literacy and why does it matter? Examining education, individual differences, and democratic outcomes. Journalism \& Mass Communication Educator, 73(2), 167-182. https://doi.org/10.1177/1077695817706572

Tully, M., \& Vraga, E. K. (2018b). A mixed-methods approach to examining the relationship between news media literacy and political efficacy. International Journal of Communication, 12, 766787. https://ijoc.org/index.php/ijoc/article/view/7467

van Deursen, A.J.A.M., Helsper, E.J., \& Eynon, R. (2014). Measuring Digital Skills: From Digital Skills to Tangible Outcomes Project Report. https://www.oii.ox.ac.uk/research/projects/?id=112

Verma, P. (2021). A Harvard professor predicted COVID disinformation on the web. Here's what may be coming next. The Boston Globe. https://www.bostonglobe.com/2021/08/23/business/ harvard-professor-predicted-covid-disinformationweb-heres-what-may-be-coming-next/

Vickery, J. (2016). Worried about the wrong things. The MIT Press.

Villa-Nicholas, M. (2019). Latinx digital memory: Identity making in real time. Social media + Society.https://doi.org/10.1177/2056305119862643

Weaver, A., \& Frampton, J. (2019). Crossing the color line: An examination of mediators and a social media intervention for racial bias in selective exposure to movies. CommunicationMonographs, 86(4), 399415. https://doi.org/10.1080/03637751.2019.1613670

Wineburg, S., McGrew, S., Breakstone, J., \& Ortega, T. (2016). Evaluating information: The cornerstone of 
civic online reasoning. Stanford Digital Repository. http://purl.stanford.edu/fv751yt5934

Wood, G. (2020, September 30). Few Americans care about democracy. The Atlantic. https://www.theatlantic.com/ideas/archive/2020/09/ few-americans-care-about-democracy/616534/

Yosso, T. J. (2002) Critical race media literacy: Challenging deficit discourse about Chicanas/os. Journal of Popular Film and Television, 30(1), 5262. https://doi.org/10.1080/01956050209605559

Zimmerman, A., \& Shresthova, S. (2012). DREAMing out loud!: Youth activists spoke about their fight for education, immigrant rights and justice through media and art. Confessions of an Aca-Fan. http://henryjenkins.org/blog/2012/01/dreaming_out _loud_youth_activi.html 